DOI: https://doi.org/10.47405/mjssh.v6i10.1075

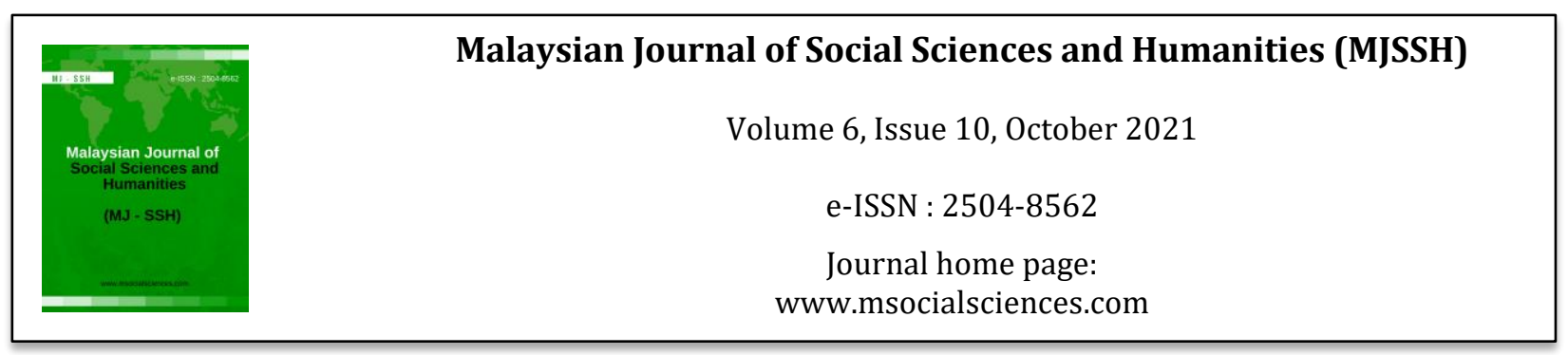

\title{
Cabaran Penguatkuasaan Penghakiman Mahkamah Syariah: Kajian Peranan Bahagian Sokongan Keluarga Terhadap Hak Wanita dan Kanak-Kanak di Sarawak
}

\author{
Zulzaidi Mahmod', Ahmad Hidayat Buang1, Afifah Baharuddin' \\ 1Jabatan Syariah dan Undang-undang, Akademi Pengajian Islam, Universiti Malaya (UM), Malaysia
}

Correspondence: Zulzaidi Mahmod (zulzaidi86@gmail.com)

\begin{abstract}
Abstrak
Penghakiman yang diputuskan oleh Hakim Syarie di Mahkamah Syariah hendaklah dipatuhi oleh pihak-pihak. Ketidakpatuhan penghakiman Mahkamah Syariah akan memberikan kesan terhadap wanita dan kanak-kanak dari aspek kewangan. Penguatkuasaan dan pelaksanaan penghakiman boleh diambil tindakan di Mahkamah Syariah. Artikel ini bertujuan melihat cabaran penguatkuasaan penghakiman yang memfokuskan kepada fungsi dan peranan Bahagian Sokongan Keluarga Jabatan Kehakiman Syariah Malaysia di Sarawak. Pendekatan metodologi yang diguna pakai bagi kajian ini ialah pendekatan kualitatif. Penyelidikan mendapati bahawa Bahagian Sokongan Keluarga (BSK), Jabatan Kehakiman Syariah Malaysia (JKSM) yang ditempatkan di Sarawak merupakan satu langkah yang proaktif diambil oleh JKSM untuk memastikan penghakiman Mahkamah Syariah dipatuhi oleh pihak Penghutang Penghakiman. Penguatkuasaan penghakiman yang dilaksanakan adalah penghakiman nafkah anak, nafkah isteri, nafkah eddah dan mutaah dikuatkuasakan melalui mekanisme perundangan yang berkuat kuasa di Sarawak. Terdapat beberapa cabaran dalam pelaksanaan penguatkuasaan penghakiman di Sarawak yang telah diambil tindakan dan langkah pemerkasaan oleh pihak JKSM dan Jabatan Kehakiman Syariah Sarawak. Pemerkasaan bahagian ini dilakukan secara holistik dan optimum dari segi kekangan kakitangan, fasiliti dan kompetensi pegawai.
\end{abstract}

Kata kunci: bahagian sokongan keluarga, penguatkuasaan perintah, Sarawak, hak wanita, hak kanakkanak

\section{Challenges in Enforcement of Syariah Court Judgment: Study of The Role of The Family Support Division on The Rights of Women and Children in Sarawak}

\begin{abstract}
The judgment decided by the Syariah Judge in the Syariah Court shall be complied with by the parties. Non-compliance with Syariah court judgments will have a financial impact on women and children. Enforcement and execution of judgments can be taken action in Syariah Courts. This research paper is aimed to view the challenges of judgment enforcement focusing on the functions and roles of the Family Support Division of the Department of Syariah Judiciary Malaysia in Sarawak. The methodological approach of the study which this paper is based is a qualitative approach. The study has revealed that BSK JKSM located in Sarawak is a proactive step taken by JKSM to ensure that the judgment of the Syariah Court is complied with by the Judgment Debtor. The enforcement of the
\end{abstract}


judgment is that the judgment of child maintenance, wife's maintenance, eddah maintenance and mutaah is enforced through the legal mechanism in force in Sarawak. There are several challenges in the implementation of judgment enforcement in Sarawak that have been taken action and empowerment measures by the JKSM and Department of Syariah Judiciary Sarawak. The empowerment of this division is done holistically and optimally in terms of staff constraints, facilities and officer competencies.

Keywords: family support division, enforcement of judgment, Sarawak, women's rights, children's rights

\section{Pengenalan}

Penguatkuasaan dan pelaksanaan penghakiman bagi kes-kes yang diputuskan oleh Hakim Syarie di Mahkamah Syariah merupakan mekanisme bagi memastikan penghakiman tersebut dilaksanakan sebagaimana diperintahkan. Perintah yang dikeluarkan oleh mahkamah merupakan suatu keputusan penghakiman yang mesti dipatuhi (Zaini Nasohah, 2009). Prosiding penguatkuasaan penghakiman merupakan proses pasca penghakiman yang mana dilakukan kerana keingkaran perintah induk sesuatu kes. Keingkaran pelaksanaan perintah ini merupakan satu penganiayaan terutamanya apabila melibatkan hak wanita dan hak kanak-kanak seperti kes nafkah anak, nafkah isteri, nafkah eddah dan mutaah. Institusi kehakiman Syariah di Malaysia telah memberi ruang kepada pihak yang teraniaya untuk menguatkuasakan perintah yang telah diputuskan berdasarkan undang-undang yang telah diwartakan. Hal ini menunjukkan bahawa Mahkamah Syariah melalui peranan Hakim Syarie bukan hanya memutuskan kes induk sahaja, tetapi mempunyai tanggungjawab membicarakan dan memutuskan kes pasca penghakiman demi memastikan keadilan ditegakkan. Penyelidikan ini memfokuskan perbincangan terhadap fungsi Bahagian Sokongan Keluarga (BSK) Jabatan Kehakiman Syariah Malaysia (JKSM) yang melaksanakan tanggungjawab menguatkuasakan penghakiman hak wanita dan hak kanak-kanak berdasarkan undang-undang yang berkuatkuasa. Penubuhan BSK membawa dimensi baru bagi masyarakat Islam di Malaysia untuk mendapatkan layanan penguatkuasaan dan pelaksanaan yang lebih efisien (Agustin \& Mohamad Hedhayatullah, 2018). Penyelidikan telah memfokuskan kepada cabaran penguatkuasaan penghakiman khusus di Wilayah Sarawak untuk menilai dan mengkaji apakah cabaran yang dihadapi oleh BSK JKSM dalam menguatkuasakan penghakiman tersebut.

\section{Sorotan Literatur}

\section{Penghakiman dan Penguatkuasaan Penghakiman Menurut Perspektif Perundangan Kehakiman Syariah di Malaysia}

Institusi kehakiman Syariah di Malaysia melalui peranan Mahkamah Syariah Negeri (MSN) mempunyai fungsi yang jelas sebagaimana dinyatakan dalam Perlembagaan Persekutuan di bawah Jadual Kesembilan, Senarai 2 Butiran 1, Senarai Negeri. Perwujudan institusi ini bertujuan untuk memastikan keadilan ditegakkan melalui institusi yang diiktiraf dan dilaksanakan oleh pihak yang kompeten (Zulzaidi \& Ahmad Hidayat, 2021). Sesebuah institusi kehakiman Islam memerlukan kepada beberapa elemen utama seperti mahkamah, Hakim Syarie, pegawai mahkamah, pendaftar mahkamah, bailif, Peguam Syarie, Pendakwa Syarie dan sebagainya (Zulzaidi \& Ahmad Hidayat, 2016). Pegawai Mahkamah Syariah yang berperanan utama dalam menghakimi sesuatu kes adalah Hakim Syarie yang dilantik mengikut Undang-undang Pentadbiran Agama Islam Negeri atau Undangundang Mahkamah Syariah Negeri. Kompetensi Hakim Syarie daripada peringkat Mahkamah Rendah Syariah (MRS) sehinggalah Panel Rayuan Mahkamah Rayuan Syariah (MRyS) negeri-negeri dibuat berpandukan undang-undang. Oleh yang demikian, penghakiman yang diputuskan dibuat oleh pihak yang berkelayakan dan mempunyai kompetensi yang ditetapkan. Keputusan dan penghakiman yang dibuat oleh hakim bicara akan dibacakan oleh hakim tersebut sebagaimana Sek. 130(2), Akta Tatacara Mal Mahkamah Syariah (Wilayah-wilayah Persekutuan) 1998 (Akta 585). Penghakiman juga boleh 
dibacakan oleh mana-mana hakim lain atau oleh pendaftar di mahkamah terbuka sebagaimana Sek. 130(3), Akta 585 kepada pihak-pihak yang hadir.

Peranan utama Hakim Syarie adalah memutuskan kes melalui prosiding dan prosedur yang ditetapkan melalui perundangan yang diwartakan. Penghakiman dilakukan melalui undang-undang utama (substantive law) dan undang-undang prosedur (procedural law). Institusi kehakiman Syariah di Malaysia adalah di bawah bidang kuasa negeri, maka undang-undang yang terpakai dalam prosiding penghakiman adalah seperti Enakmen/ Ordinan/Akta pentadbiran agama Islam, keluarga Islam, tatacara mal, jenayah Syariah, tatacara jenayah Syariah dan lain-lain. Penghakiman atau perintah yang dikeluarkan oleh mahkamah adalah suatu keputusan yang mesti dipatuhi (Zaini Nasohah, 2009). Penghakiman yang diputuskan oleh Hakim Syarie hendaklah dipatuhi dan dilaksanakan oleh pihakpihak yang bertikai dan pihak-pihak yang dinamakan dalam perintah dan penghakiman tersebut sebagaimana terma-terma yang diputuskan.

Keingkaran, kegagalan dan kecuaian dalam melaksanakan penghakiman yang diputuskan tersebut boleh dikuatkuasakan dan dilaksanakan melalui proses pasca penghakiman di Mahkamah Syariah. Apabila perintah nafkah isteri atau nafkah anak telah diperoleh dari mahkamah, maka pemiutang penghakiman berhak memfailkan pelaksanaan saman penghutang penghakiman sekiranya terdapat tunggakan hutang (Mohd Hazwan \& Jasni Sulong 2021).

Dalam melaksanakan penguatkuasaan mana-mana undang-undang, ianya perlu ada bidang kuasa yang ditetapkan bagi memberi keupayaan kepada individu atau agensi untuk melakukan tindakan (Zurul \& Zaini, 2019). Peruntukan undang-undang melalui akta dan enakmen di negeri-negeri telah menetapkan beberapa cara untuk penguatkuasaan dan pelaksanaan perintah nafkah (Zaini, 2009). Terdapat beberapa mekanisme penguatkuasaan pelaksanaan penghakiman berpandukan undang-undang. Mekanisme ditakninkan oleh undang-undang inter alia saman penghutang penghakiman, sita jual, hiwalah, pemilikan dan hantar serah (Mohamed Faouzi et al., 2021). Pra Syarat utama kepada penguatkuasaan penghakiman adalah kesahan perintah induk. Penghakiman atau perintah tersebut hendaklah diserahkan kepada pihak dikehendaki melaksanakan penghakiman atau perintah tersebut (Mohamed Faouzi et al., 2021).

Terdapat beberapa kes penguatkuasaan pelaksanaan penghakiman di peringkat MRyS di Malaysia. Beberapa prinsip penghakiman juga telah dikeluarkan untuk membantu prosiding di peringkat Mahkamah Tinggi Syariah (MTS) dan MRS di Malaysia untuk menghormati penghakiman yang lebih tinggi sebagaimana kehendak Arahan Amalan JKSM No. 1 Tahun 2002.

Penulisan Teks Alasan Penghakiman (AP) berkenaan dengan kes penguatkuasaan penghakiman ini juga telah dibuat oleh Panel Rayuan MRyS untuk mengemukakan hujah kes tersebut. Mahkamah Rayuan Syariah Wilayah Persekutuan melalui kes Abdul Sany Faizal Abdul Rahman lwn. Zulraini Dato`Zulkifli (Kes Mal No. 14000-037-0001-2009) telah memutuskan berkenaan dengan kaedah perjalanan kes Saman Penghutang Penghakiman (SPP) bagi kes nafkah anak. Panel Rayuan telah mengulas bahawa "SPP tidak boleh difailkan tanpa adanya perintah muktamad mengenai jumlah tunggakan tersebut". Panel Rayuan dalam kes ini yang dipengerusikan oleh YAA Tan Sri Haji Ibrahim Lembut dan dipersetujui oleh dua (2) panel yang lain pada 5 Julai 2010 telah memutuskan bahawa Perintah Mahkamah Tinggi Syariah Wilayah Persekutuan bagi kes ini adalah diketepikan dan dibatalkan. Perkara ini menunjukkan bahawa AP Hakim Syarie di Mahkamah Syariah amat penting bagi mengulas isu-isu yang dibangkitkan di dalam mahkamah untuk memberi kefahaman berkenaan proses perundangan dalam sistem kehakiman.

Kebebasan dalam melaksanakan proses perundangan telah dilaksanakan di Mahkamah Syariah di Malaysia. Merujuk kepada AP kes Mohd Yusoff bin Ali lwn. Zaharah binti Ayob (Kes Mal No. 070000-037-0005-2019) MRyS Pulau Pinang yang telah diputuskan melalui 2 Panel Rayuan berkenaan dengan proses SPP ini. Panel Rayuan telah menyatakan dalam perenggan [22] "Dengan hormatnya kami tidak bersetuju dengan ulasan Panel Rayuan terhadap prinsip-prinsip yang telah diputuskan dalam kes Abdul Sany Faizal Abdul Rahman lwn. Zulraini Dato`Zulkifli Kes (Rayuan) Mal No. 14000-037-0001-2009 (belum dilaporkan) ...”. Bahkan Panel Rayuan telah membuat 
keputusan melalui perenggan [24] "Berdasarkan ulasan-ulasan di atas, kami berpandangan bahawa prosiding SPP boleh dimulakan oleh Responden tanpa perlu memfailkan tuntutan tunggakan nafkah terlebih dahulu kerana jumlah tunggakan nafkah masih boleh dimuktamadkan oleh Mahkamah".

Penyelidikan mendapati bahawa kedua-dua kes di peringkat MRyS mempunyai perbezaan pendapat melalui teks AP yang tulis. Hal ini menunjukkan bahawa proses kehakiman Syariah di Malaysia mempunyai kebebasan kehakiman dalam membuat penghakiman sesuatu kes di Mahkamah Syariah. Berdasarkan kedua-dua kes yang dinyatakan di atas jelas menunjukkan bahawa Mahkamah Syariah di Malaysia amat memberi penekanan terhadap proses penguatkuasaan pelaksanaan penghakiman melalui saluran undang-undang. Kefahaman terhadap isu-isu yang dibangkitkan dalam kes juga dapat dilihat dan dinilai melalui teks AP yang dikeluarkan oleh Panel Rayuan untuk melancarkan kefahaman pihak-pihak terhadap proses penguatkuasaan pelaksanaan penghakiman Mahkamah Syariah.

Menelusuri kerangka penghakiman dan penguatkuasaan pelaksanaan penghakiman menurut perspektif perundangan Islam, sebenarnya telah dibincangkan oleh banyak sarjana Islam di dalam kitab-kitab mereka. Ulama' kontemporari yang membincangkan berkenaan dengan penguatkuasaan pelaksanaan hukuman adalah `Abd al-Karim Zaydan (2011) di dalam kitabnya Nizam al-Qada 'fi al-Shari`ah alIslamiyyah dan Muhammad al-Zuhaylī (2011) di dalam kitabnya al-Mu`tamad. Kedua-dua ulama ini meletakkan tajuk khusus kepada perbincangan penguatkuasaan hukuman di bawah tajuk "Tanfidh alHukm" ('Abd al-Karim Zaydan, 2011) dan "Tanfidh al-Ahkam" (Muhammad al-Zuhayli, 2011). `Abd al-Karim Zaydan (2011) dalam penulisannya juga meletakkan bahawa adalah dibenarkan seseorang hakim menulis surat kepada hakim lain untuk tujuan pelaksanaan penghakiman atau dinamakan dengan kaedah Kitab al-Qadi ilā al-Qadi. Perkara ini juga dibincangkan oleh Ibn Qudamah (2004) dan al-Husayni (2001) di dalam kitab mereka.

Oleh yang demikian, aplikasi dan proses penghakiman dan penguatkuasaan penghakiman merupakan satu tugasan kehakiman berdasarkan perspektif Hukum Syarak dan juga pengamalan di Mahkamah Syariah yang berpandukan kepada undang-undang yang berkuatkuasa. Tujuan proses penghakiman dan penguatkuasaan penghakiman adalah untuk memastikan keadilan tertegak melalui institusi yang telah dibentuk oleh Perlembagaan Persekutuan.

\section{Metod Kajian}

Pengumpulan data penyelidikan ini dilakukan secara kepustakaan, dokumentasi dan temu bual pihak berkaitan. Temu bual dilakukan bagi mendapatkan maklumat terkini berkenaan pelaksanaan penguatkuasaan penghakiman. Dokumentasi yang diperolehi telah dihurai dan dijelaskan oleh informan berdasarkan sub isu yang dibangkitkan dalam dapatan kajian. Temu bual dilakukan serentak dengan setiap informan agar aliran maklumat yang diperoleh didapati secara menyeluruh dan sempurna. Penyelidikan dilakukan melalui metodologi kualitatif terhadap fungsi dan peranan BSK JKSM di Sarawak. Proses penyelidikan dilakukan secara berstruktur dengan penjadualan yang dibuat secara rapi bagi memastikan dapatan kajian adalah relevan.

\section{Hasil Kajian}

\section{Bahagian Sokongan Keluarga, Jabatan Kehakiman Syariah Malaysia}

Bahagian Sokongan Keluarga (BSK) merupakan sebuah bahagian di bawah Jabatan Kehakiman Syariah Malaysia (JKSM). JKSM di bawah Jabatan Perdana Menteri (JPM) berperanan sebagai koordinator dan penyelaras perihal berkaitan perundangan dan kehakiman kepada institusi kehakiman Syariah negeri-negeri di Malaysia. BSK ditubuhkan bagi mengendalikan kes-kes penguatkuasaan dan pelaksanaan perintah nafkah isteri dan nafkah anak di Mahkamah Syariah negeri-negeri (Mohd Amir Arifin, 2021). Permasalahan ini memberikan kesan dan tempias kepada Mahkamah Syariah dari segi pematuhan kepada perintah yang telah dikeluarkan melalui prosiding mahkamah (BSK JKSS, 2021). 
BSK ditubuhkan di Mahkamah Syariah kerana isu tuntutan nafkah dan penguatkuasaannya sering menjadi rungutan terutama di kalangan isteri atau isteri yang diceraikan atau ibu kepada kanak-kanak yang diceraikan (Sidang Parlimen, 2017). Mesyuarat Majlis Kebangsaan Bagi Hal Ehwal Ugama Islam Malaysia (MKI) Kali ke-46 pada 7 Jun 2007 yang dipengerusikan oleh Dato' Seri Abdullah Bin Hj. Ahmad Badawi iaitu YAB Perdana Menteri pada ketika itu memutuskan supaya JKSM mengambil tindakan segera bagi menyelesaikan isu nafkah (Roslina et al., 2017). Memastikan satu tindakan yang lebih efektif dan proaktif diambil bagi menangani perkara ini maka, JKSM telah mewujudkan BSK dan menempatkan di setiap negeri di Malaysia.

Penubuhan BSK ini sebagai langkah yang telah diambil oleh Kerajaan bagi menambah baik mekanisme penguatkuasaan perintah mahkamah pasca penceraian dalam kalangan orang Islam (Sidang Parlimen, 2019). Penubuhan dan pelancaran BSK JKSM ditubuhkan secara rasminya pada 22 Oktober 2008 oleh YB Dato' Seri Dr. Ahmad Zahid bin Hamidi, Menteri di Jabatan Perdana Menteri di JKSM (BSK JKSS, 2021). Bagi memastikan fungsi dan peranan BSK JKSM dijalankan secara proaktif dan efisien maka JKSM telah menempatkan BSK di setiap Mahkamah Syariah Negeri di Malaysia. JKSM telah menempatkan 6 kakitangan BSK di setiap negeri bagi menjalankan tugas penguatkuasaan dan pelaksanaan perintah. Semua kakitangan BSK di negeri-negeri merupakan perjawatan di bawah JKSM yang mana segala urusan pentadbiran, pengurusan dan pembayaran gaji adalah diuruskan oleh JKSM di Putrajaya walaupun kakitangan bertugas di negeri (Mohd Sufi, 2021).

\section{Fungsi dan Peranan Bahagian Sokongan Keluarga Jabatan Kehakiman Syariah Malaysia (Seksyen Sarawak) Terhadap Hak Wanita dan Kanak-Kanak}

BSK JKSM juga telah ditempatkan di Wilayah Sarawak. Penempatan kakitangan BSK ini telah diletakkan di Jabatan Kehakiman Syariah Sarawak (JKSS) yang berpusat di bangunan Ibu Pejabat Mahkamah Syariah Sarawak di Kuching (BSK JKSS, 2021). Penyelidikan memfokuskan kepada BSK JKSM (Seksyen Sarawak) memandangkan faktor geografi yang luas dengan jumlah kakitangan yang sama di setiap negeri di Malaysia. Maklumat Pengurusan BSK JKSM di Sarawak adalah sebagaimana jadual di bawah:

Jadual 1: Maklumat Pengurusan BSK JKSM (Seksyen Sarawak)

\begin{tabular}{|c|c|c|c|}
\hline BIL & PERKARA & MAKLUMAT & PENJELASAN \\
\hline 1 & $\begin{array}{l}\text { Kakitangan BSK JKSM } \\
\text { (Seksyen Negeri } \\
\text { Sarawak) }\end{array}$ & 6 orang & $\begin{array}{l}\text { LS44- Penolong Pengarah Kanan (1) } \\
\text { LS41- Penolong Pengarah (1) } \\
\text { LS29- Penolong Pegawai Syariah (2) } \\
\text { W29- Penolong Akauntan (1) } \\
\text { LS17-Pembantu Syariah (1) }\end{array}$ \\
\hline 2 & $\begin{array}{l}\text { Jumlah Bahagian di } \\
\text { Sarawak }\end{array}$ & 11 Bahagian & $\begin{array}{l}\text { Kuching, Kota Samarahan, Sri Aman, } \\
\text { Betong, Sibu, Sarikei, Mukah, Bintulu, } \\
\text { Miri, Kapit, (Limbang \& Lawas) }\end{array}$ \\
\hline 3 & $\begin{array}{l}\text { Pengangkutan } \\
\text { menjalankan tugas di } \\
\text { Bahagian Sarawak } \\
\text { (prosiding kes, program } \\
\text { literasi maklumat) }\end{array}$ & $\begin{array}{l}\text { Kapal Terbang } \\
\text { Twin Otter } \\
\text { Pacuan } 4 \text { Roda } \\
\text { Kereta JKSS } \\
\text { Feri Sungai } \\
\text { Boat Express }\end{array}$ & $\begin{array}{l}\text { Pengangkutan adalah berdasarkan lokasi } \\
\text { dan juga fasiliti pengangkutan yang } \\
\text { bersesuaian. } \\
\text { (Kemaskini } 1 \text { Mac 2021) }\end{array}$ \\
\hline 4 & $\begin{array}{l}\text { Keluasan Geografi } \\
\text { Sarawak }\end{array}$ & $\begin{array}{l}124,450 \mathrm{~km} \text { persegi } \\
\text { atau } \\
37.7 \% \text { keluasan } \\
\text { Malaysia }\end{array}$ & $\begin{array}{l}\text { Sarawak merupakan negeri yang terbesar } \\
\text { di Malaysia dengan keluasan } 124,450 \mathrm{~km}^{2} \\
\text { dan populasi sebanyak } 2.5 \text { juta (Prashobh } \\
\text { Karunakaran, 2014). }\end{array}$ \\
\hline
\end{tabular}

Berdasarkan jadual 1 di atas menunjukkan berkenaan pengurusan BSK JKSM di Sarawak yang mempunyai bilangan kakitangan seramai 6 orang (kemaskini sehingga 1 Mac 2021). Berdasarkan 
empat (4) perkara yang ditunjukkan di atas adalah menjelaskan tugasan kakitangan BSK adalah menjalankan fungsi yang luas dan besar dari aspek geografi di Sarawak. Menjalankan usaha penguatkuasaan dan pelaksanaan penghakiman Hakim Syarie di 11 Bahagian di Sarawak merupakan cabaran besar terhadap tanggungjawab ini yang akan dibincangkan di dalam sub topik cabaran penguatkuasaan dan pelaksanaan penghakiman (Mohd Sufi, 2021).

Pada menjalankan tugas BSK terhadap hak wanita maka tiga unit utama diwujudkan untuk memudahkan urusan pengurusan secara teratur dan terancang (Abdul Karim \& Zulzaidi, 2020). Unit yang tersebut adalah Unit Khidmat Nasihat Perundangan (UKNP), Unit Pengurusan Dana (UPD) dan Unit Penguatkuasaan dan Pelaksanaan Perintah (UPPP) (Roslina Che Soh et al., 2017). Perkara ini boleh dirujuk melalui rajah di bawah:

\section{Rajah 1: Unit-unit di Bawah Pengurusan BSK JKSM Seksyen Negeri}

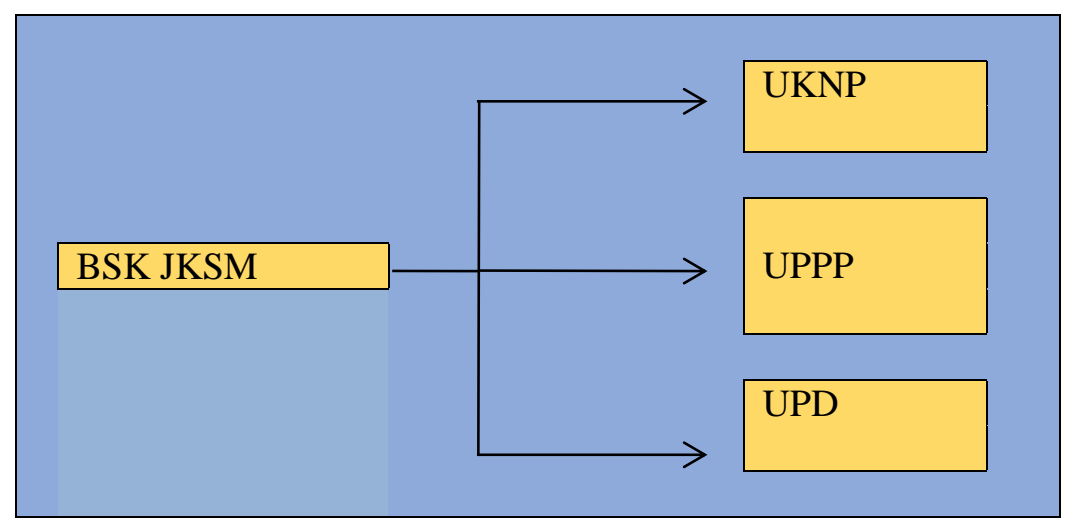

Unit-unit ini mempunyai peranan dan fungsi tersendiri secara khusus terhadap proses pelaksanaan perintah dan secara tidak langsung membantu memperkasa hak wanita dan hak kanak-kanak. Peranan unit-unit tersebut adalah seperti berikut:

\section{Unit Khidmat Nasihat Perundangan (UKNP)}

UKNP menjalankan fungsi dengan memantau perintah-perintah berkaitan nafkah anak, nafkah isteri, nafkah eddah dan mutaah yang telah diperintahkan oleh Mahkamah Syariah. UKNP secara dasarnya adalah berfungsi dengan menerima aduan daripada pengadu berkenaan ketidakpatuhan, kegagalan dan kecuaian melaksanakan perintah (nafkah isteri, nafkah eddah, nafkah anak, tunggakan nafkah dan mutaah) yang telah dikeluarkan oleh Mahkamah Syariah. UKNP juga akan mendaftarkan kes-kes permohonan kegagalan melaksanakan perintah nafkah melalui sistem e-nafkah sebagai sistem simpanan data atas talian (Nur Zulfah \& Nur Syazwani, 2020). UKNP akan membuat siasatan terhadap setiap kes yang diadukan. Sekiranya suami atau bapa anak tersebut didapati gagal melaksanakan perintah tersebut, maka Pegawai BSK di unit ini akan menjalankan satu proses perbincangan yang dinamakan mediasi atau runding cara (BSK JKSS, 2021). UKNP bertanggungjawab mengendalikan sesi khidmat nasihat kepada pelanggan BSK iaitu pengadu dalam kes tuntutan nafkah anak (Jabatan Kehakiman Syariah Malaysia, 2017). Sekiranya sesi runding cara mencapai persetujuan pihak-pihak maka UKNP akan menyediakan perjanjian persetujuan yang akan ditandatangani pihak-pihak (Nur Zulfah \& Nur Syazwani, 2020). Perjanjian tersebut akan diendors di hadapan Hakim Syarie dan dijadikan perintah Mahkamah Syariah (Mohd Sufi, 2021). Walau bagaimanapun, sekiranya tiada persetujuan dibuat maka proses tindakan akan dipanjangkan kepada pihak UPPP untuk tindakan prosiding kes.

\section{Unit Penguatkuasaan Dan Pelaksanaan Perintah (UPPP)}

UPPP menjalankan fungsi untuk memastikan semua perintah yang dikeluarkan dipatuhi oleh bekas suami sebagai penghutang penghakiman (Roslina et al., 2017). UPPP juga melakukan proses tindakan diambil terhadap penghutang penghakiman yang ingkar perintah mahkamah melalui prosiding di Mahkamah Syariah. UPPP berperanan membantu pihak-pihak yang teraniaya dengan menjalankan 
tugas sebagai Peguam Syarie dan Bailif Mahkamah (BSK JKSS, 2021). UPPP bertindak menguruskan proses guaman Syarie yang akan dikendalikan oleh Pegawai BSK yang berkelayakan untuk mengendalikan kes di peringkat Mahkamah Syariah (Mohd Sufi, 2021). Peguam Syarie akan menghadiri prosiding sehingga mahkamah memerintahkan berkenaan perintah penguatkuasaan pelaksanaan penghakiman (Mohd Na'im, 2015). UPPP juga melaksanakan proses waran tangkap ke atas penghutang penghakiman. Terdapat juga prosedur lain yang boleh dijalankan oleh UPPP seperti penyitaan dan penjualan, hiwalah dan prosiding lain sebagaimana permohonan dan perintah yang dikeluarkan oleh mahkamah.

\section{Unit Pengurusan Dana (UPD)}

UPD menjalankan fungsi untuk mengurus akaun amanah BSK JKSM Seksyen Negeri. Selain itu BSK JKSM (seksyen Sarawak) juga menguruskan Akaun Amanah Bantuan Sokongan Keluarga JKSS sebagaimana yang telah diluluskan oleh pihak Setiausaha Kewangan Negeri Sarawak (Enelda Nurizzati, 2021). Seterusnya UPD akan membuat siasatan untuk menentukan kesahihan butiran yang dikemukakan pengadu (Laman Web Rasmi Mahkamah Syariah Negeri Melaka, 2021). UPD akan menilai latar belakang pihak pemohon iaitu pemiutang penghakiman atau pihak yang berkepentingan sebagaimana ketetapan syarat Jawatankuasa Akaun Amanah BSK JKSS (Enelda, 2021). UPD BSK (Seksyen Sarawak) adalah menguruskan dua jenis saluran dana iaitu bantuan dana dan pendahuluan dana (BSK JKSS, 2021). UPD akan bermesyuarat secara dalaman dengan pegawai BSK JKSM di Sarawak yang akan menilai setiap kandungan permohonan sebelum dipanjangkan kepada Jawatankuasa Akaun Amanah BSK JKSS (JKAAB) untuk pertimbangan kelulusan dana. Pertimbangan JKAAB adalah dari segi pemberian Pendahuluan Dana (PD) atau Bantuan Dana (BD) (Mohd Sufi, 2021). PD juga ada disebut dengan istilah pendahuluan nafkah dan BD juga ada disebut dengan istilah pendahuluan nafkah. UPD akan menguruskan akaun amanah sebagaimana kehendak pihak Setiausaha Kewangan Negeri Sarawak dengan pemantauan daripada pihak JKSS dan juga JKSM (Mohd Sufi, 2021).

\section{Cabaran Penguatkuasaan Penghakiman Hak Wanita dan Kanak-Kanak Berdasarkan Peranan BSK JKSM di Sarawak}

Cabaran pentadbiran dan pengurusan organisasi di peringkat jabatan kerajaan merupakan perkara yang sentiasa diambil cakna oleh setiap organisasi bagi memastikan keberkesanan penyampaian perkhidmatan. Perkara ini juga diberi penekanan oleh BSK JKSM di Sarawak bagi memastikan hak wanita dan hak kanak-kanak dari aspek kes nafkah diberikan perhatian melalui saluran perundangan dan kehakiman. Penyelidik mendapati terdapat beberapa cabaran penguatkuasaan penghakiman yang dihadapi oleh BSK JKSM di Sarawak berdasarkan fungsi dan peranan yang dilakukan. Cabaran yang berkaitan penguatkuasaan penghakiman ini lebih menjurus kepada pengurusan pentadbiran, undangundang, literasi dan latihan kakitangan.

\section{Kekangan kakitangan dan keluasan Geografi Tugasan BSK di Sarawak}

Kekangan kakitangan merupakan cabaran utama kepada penguatkuasaan penghakiman melalui fungsi BSK. Berdasarkan jadual 1 di atas menunjukkan jumlah kakitangan hanya terdapat 6 orang sahaja yang ditempatkan di Sarawak. Kakitangan BSK di Sarawak mempunyai jumlah yang sama dengan kakitangan BSK di Jabatan Kehakiman Syariah Negeri (JKSN) serta MSN. BSK JKSM di Sarawak perlu mengendalikan kes dengan faktor geografi di Sarawak yang luas berbanding negeri lain yang kecil seperti Perlis, Melaka dan Negeri Sembilan (Abdul Karim \& Zulzaidi, 2020). Sarawak merupakan negeri yang terbesar di Malaysia dengan keluasan $124,450 \mathrm{~km}^{2}$ dan populasi sebanyak 2.5 juta (Prashobh, 2014). Keluasan Sarawak boleh dirujuk sebagaimana peta di bawah: 


\section{Rajah 2: Peta Sarawak}

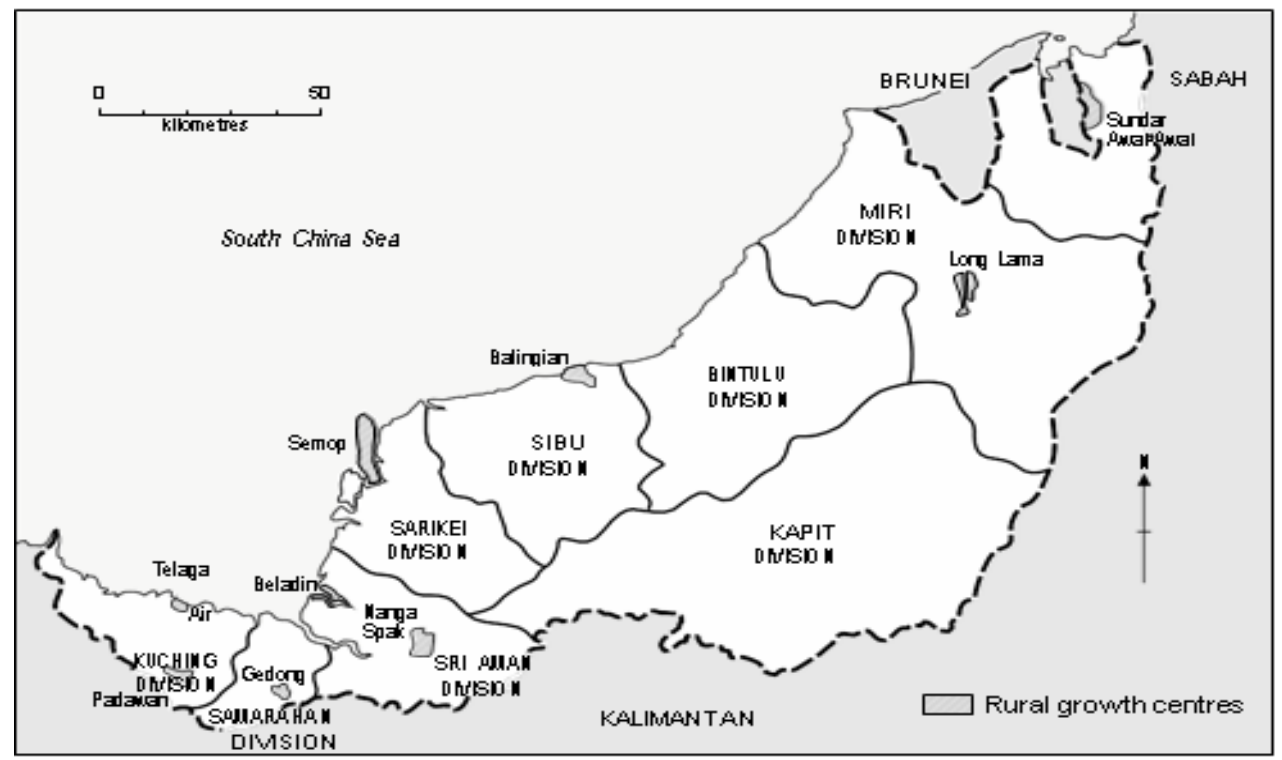

Sumber: Fadzilah (2003)

Sarawak telah mencatatkan jumlah penduduk seramai 2,907,500 pada tahun 2020 berbanding seramai 2,471,140 pada tahun 2010 (The Official Portal of Sarawak Government, 2021). Jumlah penduduk Islam di Sarawak adalah seramai 796,239 orang atau 32.22\% pada tahun 2010 sebagaimana bancian yang dilakukan oleh Jabatan Perangkaan Malaysia (2021). BSK JKSM di Sarawak melaksanakan tugasan penguatkuasaan di 11 bahagian di Sarawak dengan pembahagian tiga (3) zon utama iaitu Zon Selatan, Zon Tengah dan Zon Utara. Pihak JKSS telah mengambil inisiatif dengan cadangan mewujudkan beberapa jawatan kakitangan BSK secara lantikan negeri berdasarkan "Jawatan Berasaskan Caruman" yang akan ditempatkan di JKSS Ibu Pejabat, JKSS Sibu dan JKSS Miri (Abdul Karim \& Zulzaidi, 2020). Sebelum ini semua perkhidmatan guaman dan runding cara BSK adalah dikendalikan oleh kakitangan BSK daripada Ibu Pejabat di Kuching. Penyelidikan juga melihat bahawa keperluan penambahan kakitangan BSK di Sarawak wajar ditambah di Zon Utara (Bahagian Miri) dan Zon Tengah (Bahagian Sibu). Perkara ini telah ditunjukkan oleh Jabatan Bantuan Guaman (JBG) yang mana telah menempatkan kakitangan lantikan JKSM di kedua-dua Zon bagi melancarkan perkhidmatan guaman Syarie di zon tersebut. Perkara ini juga dapat membantu pengurusan literasi maklumat kepada masyarakat yang lebih komprehensif di zon tersebut. Masyarakat juga perlu ada kesedaran untuk mendalami dan mempelajari ilmu berkenaan perkahwinan, perceraian dan rujuk untuk memantapkan pemahaman mereka (Raihanah \& Zulzaidi, 2010). Sekiranya cabaran kakitangan ini dapat ditangani maka penawaran perkhidmatan BSK dapat dimudahkan melalui fungsi kakitangan di peringkat zon utara dan zon tengah.

\section{Guaman Syarie BSK di Sarawak}

Fungsi dan peranan BSK adalah untuk memastikan prosiding penguatkuasaan penghakiman dijalankan melalui prosiding di Mahkamah Syariah. Perkara ini bermaksud pihak pemiutang penghakiman akan diwakili oleh Peguam Syarie daripada pihak BSK untuk mengendalikan kes. Dalam usaha memantapkan lagi pelaksanaan BSK seluruh negara, BSK memerlukan komitmen yang tinggi terutama penetapan dasar pelaksanaannya khususnya dalam memberikan tauliah kepada pegawaipegawai BSK bagi membolehkan mereka mewakili pihak-pihak dalam menguatkuasakan perintah nafkah di Mahkamah Syariah (Jabatan Kehakiman Syariah Malaysia, 2009). Penghakiman yang diputuskan oleh mahkamah, akan diuruskan oleh UPPP dengan pengendalian kes di Mahkamah Syariah melalui peguam Syarie (Zulzaidi, Ahmad Hidayat \& Afifah, 2021). Tauliah Peguam Syarie penting untuk memudahkan perjalanan prosiding kes yang melibatkan pelaksanaan penguatkuasaan perintah nafkah yang tertunggak (Roslina et al., 2017). 
Penempatan kakitangan BSK JKSM di Sarawak adalah pada tahun 2009. Pada waktu tersebut sehingga tahun 2012 tiada Pegawai Syariah BSK yang ditauliahkan sebagai Peguam Syarie untuk mengendalikan prosiding di Mahkamah Syariah. Walau bagaimanapun pada Ogos 2013, Yang Amat Arif Ketua Hakim Syarie (YAA KHS) JKSS telah menerima masuk seorang Pegawai Syariah BSK JKSM (Penolong Pengarah LS41) sebagai Peguam Syarie di Sarawak (Mohd Sufi, 2021). Pengendalian kes guaman Syarie penguatkuasaan penghakiman yang dilakukan adalah kes nafkah anak, nafkah eddah dan nafkah isteri yang berkait dengan hak wanita dan hak kanak-kanak. Walau bagaimanapun dari tahun Ogos 2013 sehingga April 2019 hanya seorang pegawai sahaja yang mengendalikan kes dalam tempoh tersebut. Perkara ini menyukarkan proses guaman kerana sesuatu kes yang dikendalikan di Sarawak terutama di zon utara dan zon tengah akan mengambil masa perjalanan pergi balik sekurang-kurangnya tiga (3) hari sekiranya menggunakan pengangkutan darat (Mohd Sufi, 2021). Hal ini menyebabkan tarikh perbicaraan sesuatu kes lebih panjang tangguhannya disebabkan kekangan hanya seorang Peguam Syarie sahaja yang dilantik. Pada tahun 2019 BSK JKSM di Sarawak telah membuat permohonan kepada YAA KHS JKSS dan Jawatankuasa Peguam Syarie untuk menambah bilangan Peguam Syarie BSK. Maka pada tahun 2020, terdapat 4 orang Peguam Syarie BSK JKSM di Sarawak yang dilantik sebagai Peguam Syarie dan mengendalikan kes berkaitan penguatkuasaan penghakiman di Sarawak (Khadijah, 2021). Pelantikan Peguam Syarie BSK di Sarawak memberi kelebihan besar kepada prosiding di mahkamah. Hal ini adalah kerana terdapat juga BSK di negeri lain yang tidak ditauliahkan Peguam Syarie seperti di Selangor, Johor dan Wilayah Persekutuan (Mohd Zamri, 2021). Pelantikan peguam Syarie BSK di Sarawak memudahkan prosiding guaman dan prosedur Mahkamah Syariah dalam mengendalikan kes.

Cabaran dalam pengendalian kes walaupun telah mempunyai tauliah guaman Syarie adalah cabaran pandemik covid-19 yang merupakan cabaran dalam pengendalian kes BSK di Sarawak terhadap penguatkuasaan penghakiman bermula 18 Mac 2020. Hal ini adalah kerana pandemik covid-19 telah menyebabkan terdapat kes-kes yang terpaksa ditangguhkan atas faktor keselamatan kesihatan dan tiket kapal terbang ditunda oleh pihak penerbangan bagi kes di Bahagian/Daerah (Mohd Sufi, 2021). Walau bagaimanapun bagi kes-kes pengendalian BSK di Mahkamah Syariah Kuching iaitu di MRS dan MTS tetap dikendalikan dalam tempoh pandemik covid-19 kecuali diarahkan tangguhan oleh Mahkamah Syariah (Khadijah, 2021). Pengendalian kes ini menunjukkan bahawa BSK JKSM (Seksyen Sarawak) komited menguatkuasakan penghakiman Mahkamah Syariah demi menjaga kebajikan wanita dan kanak-kanak yang teraniaya (Zulzaidi, Ahmad Hidayat \& Afifah, 2021). Perkara ini jelas menunjukkan keperluan dan kewajaran tauliah guaman Syarie BSK ini bagi membantu hak wanita dan kanak-kanak. Penubuhan BSK memberikan kesan yang besar untuk menambah baik pengurusan nafkah di Malaysia (Roslina et al., 2017). Penyelidikan mencadangkan memandangkan lantikan Peguam Syarie masih baru di BSK bagi kelengkapan empat (4) orang kakitangan, maka perlu diwujudkan satu keperluan perancangan latihan guaman Syarie khusus bagi tujuan pengendalian kes hak wanita dan kanak-kanak ini.

\section{Penguatkuasaan Penghakiman BSK di Sarawak Hanya Tertumpu Pada Saman Penghutang Penghakiman Sahaja}

Menurut Mohamed Faouzi et al. (2021) terdapat beberapa mekanisme penguatkuasaan pelaksanaan penghakiman oleh undang-undang inter alia saman penghutang penghakiman, sita jual, hiwalah, pemilikan dan hantar serah. Walau bagaimanapun, kes pengendalian BSK di Sarawak hanya tertumpu kepada SPP dan notis penghakiman sahaja semenjak tahun 2010. Perkara ini boleh dirujuk melalui statistik di jadual 2.

Berdasarkan jadual 2, didapati bahawa jumlah kes yang didaftarkan di UPPP BSK JKSM di Sarawak adalah sebanyak 417 kes dalam tempoh 11 tahun. Kesemua kes yang didaftarkan di UPPP dikendalikan di Mahkamah Syariah Sarawak melalui prosiding SPP di bawah peruntukan Seksyen 175 sehingga Seksyen 185 Ordinan Tatacara Mal Syariah 2001 (OTMS 2001) (Bab 44/2001). Peruntukan tersebut merupakan peruntukan khas berhubungan dengan SPP di bawah Bab 4 OTMS 2001. Prosiding yang dijalankan adalah kes SPP. Sekiranya pihak penghutang penghakiman gagal menjalankan penghakiman SPP tersebut, maka prosiding notis penghakiman di bawah seksyen 179 OTMS 2001 akan dilakukan. 
Jadual 2: Statistik Keseluruhan Kes UPPP BSK JKSM (Seksyen Sarawak) Tahun 2009 Sehingga Tahun $2020^{1}$

\begin{tabular}{lllll}
\hline TAHUN & $\begin{array}{l}\text { BAKI TAHUN } \\
\text { SEBELUM }\end{array}$ & DAFTAR & SELESAI & $\begin{array}{l}\text { DALAM } \\
\text { TINDAKAN }\end{array}$ \\
\hline 2009 & - & - & - & - \\
2010 & 0 & 74 & 32 & 42 \\
2011 & 42 & 31 & 36 & 37 \\
2012 & 37 & 37 & 33 & 41 \\
2013 & 41 & 33 & 20 & 54 \\
2014 & 54 & 37 & 63 & 28 \\
2015 & 28 & 34 & 23 & 39 \\
2016 & 39 & 22 & 29 & 32 \\
2017 & 32 & 39 & 27 & 44 \\
2018 & 44 & 44 & 41 & 47 \\
2019 & 47 & 43 & 54 & 36 \\
2020 & 36 & 23 & 25 & 34 \\
JUMLAH & & 417 & 383 & 34 \\
\hline
\end{tabular}

Sumber: Laporan Tahunan UPPP BSK JKSS (Kemaskini sehingga 31 Disember 2020)

Cabaran pengendalian kes BSK di Sarawak hanya tertumpu kepada satu kaedah sahaja iaitu SPP sedangkan kaedah lain tidak digunakan. Penyelidikan mendapati bahawa kaedah SPP ini lebih mudah berkenaan dengan prosiding yang melibatkan tunggakan wang. Berkenaan dengan kaedah penyitaan untuk dilakukan lebih rumit kerana sehingga 30 Julai 2021 Mahkamah Syariah Sarawak di Kuching belum mempunyai bilik sitaan bagi tujuan penyimpanan barang sitaan kerana Kompleks Bangunan Mahkamah Syariah Sarawak dalam proses baik pulih bangunan (Mohd Sufi, 2021). Pihak JKSS telah mengambil tindakan berkenaan perkara ini dah telah dimasukkan di dalam Pelan Antirasuah Organisasi (OACP) JKSS (Jabatan Kehakiman Syariah Sarawak, 2020). Keterdedahan risiko yang dinyatakan adalah ketiadaan stor penyimpanan barang sitaan di Mahkamah Syariah mengakibatkan kerosakan dan kehilangan barang sitaan. Inisiatif yang diambil berkenaan dengan perkara ini adalah mewujudkan stor penyimpanan barang sitaan di Mahkamah dan Bailif menyediakan senarai inventori untuk barangan yang disita bagi setiap penyitaan. Jangkaan tempoh masa penyelesaian permasalahan cabaran ini adalah selama 5 tahun (2021-2025) sebagaimana dinyatakan dalam OACP (Jabatan Kehakiman Syariah Sarawak, 2020). Latihan berkenaan sitaan dan prosedur penguatkuasaan selain SPP telah dilaksanakan di Mahkamah Sivil Sarawak pada tahun 2019 (Mohd Sufi, 2021). Penyelidikan mencadangkan dalam tempoh persediaan bilik sitaan di JKSS, maka kakitangan BSK yang berkaitan diberikan latihan berkenaan sitaan daripada pihak berkaitan secara berkala dan konsisten untuk memastikan kompetensi pegawai dan kakitangan yang berkaitan UPPP ini.

\section{Cabaran Ketidakhadiran Penghutang Penghakiman dalam Sesi Runding Cara dan Prosiding Mahkamah Syariah}

Pengendalian kes penguatkuasaan penghakiman yang diadukan kepada pihak BSK JKSM akan dikendalikan secara aturannya oleh UKNP sebelum dibawa kepada prosiding Mahkamah Syariah melalui UPPP. Terdapat banyak kes pengabaian nafkah berjaya diselesaikan menerusi kaedah perbincangan runding cara tanpa membabitkan prosiding kes iaitu kes tidak selesai ke tahap posiding (Agustin \& Mohamad Hedhayatullah, 2018). Kegagalan pihak penghutang penghakiman melalui UKNP akan melalui proses runding cara yang akan dikendalikan oleh Pegawai BSK JKSM di Sarawak. Keseluruhan pengendalian runding cara di BSK JKSM di Sarawak dari tahun 2009 sehingga 2020 adalah sebanyak 527 kes sebagaimana di dalam Laporan Tahunan UPD BSK JKSS (Kemaskini sehingga 31 Disember 2020). Cabaran pengendalian runding cara di BSK Sarawak adalah dari segi

\footnotetext{
${ }^{1}$ Catatan: (1) Daftar: kes yang telah didaftar di peringkat UPPP dalam sistem E-Nafkah. (2) Selesai: Kes yang telah selesai di UPPP dan telah mendapat Perintah Mahkamah. (3) Dalam tindakan: Baki kes di peringkat UPPP untuk dibawa ke tahun hadapan.
} 
kehadiran pihak penghutang penghakiman dalam sesi runding cara tersebut. Terdapat dua keadaan kegagalan ketidakhadiran penghutang dalam sesi tersebut antaranya kerana penghutang penghakiman tidak dapat ditemui dan penghutang penghakiman sengaja tidak hadir dalam sesi tersebut setelah notis kehadiran dikeluarkan (Khadijah, 2021). Perkara ini menyebabkan runding cara tidak berjaya dilaksanakan dan secara tidak langsung mekanisme penguatkuasaan penghakiman melalui metod runding cara ini memberi kesan kepada pengurusan kes (Khadijah, 2021). Faktor penghutang penghakiman tidak dapat ditemui juga merupakan faktor ketidakhadiran penghutang penghakiman dalam prosiding di peringkat UPPP di Mahkamah Syariah.

Merujuk kepada peruntukan seksyen 178 (2)(a) OTMS 2001 iaitu mahkamah boleh "memerintahkan supaya dia ditangkap dan dibawa ke hadapan Mahkamah untuk diperiksa". Hal ini menunjukkan waran tangkap boleh dikeluarkan bagi kes ketidakhadiran pihak penghutang penghakiman di Mahkamah Syariah. Cabaran ketidakhadiran ini merupakan perkara yang diberi perhatian oleh pihak JKSS melalui OACP di bawah bidang keutamaan penguatkuasaan. Risiko yang dinyatakan di dalam OACP adalah Waran Tangkap gagal dilaksanakan terhadap penghutang penghakiman. Inisiatif yang akan diambil adalah mendapatkan maklumat mengenai penghutang penghakiman melalui carian di Jabatan Pendaftaran Negara (JPN), Jabatan Imigresen, Kumpulan Wang Simpanan Pekerja (KWSP), Syarikat Telekomunikasi, Jabatan Pengangkutan Jalan (JPJ) dan lain-lain (Jabatan Kehakiman Syariah Sarawak, 2020). Perkara ini dipertanggungjawabkan kepada pihak UKNP dan UPPP BSK di Sarawak. Penyelidikan mendapati perkara ini merupakan satu inisiatif yang baik untuk memastikan kehadiran pihak penghutang penghakiman bagi pengurusan prosiding penguatkuasaan penghakiman di Mahkamah Syariah. Penyelidikan mencadangkan inisiatif ini dilaksanakan juga di peringkat rundingcara di bawah UKNP untuk memastikan penghutang penghakiman dapat ditemui melalui mekanisme ini. Hal ini juga mampu membantu kehadiran penghutang penghakiman tujuan rundingcara.

Proses kepada proses rundingcara BSK JKSM di Sarawak adalah dikendalikan oleh Penolong Pengarah Kanan LS44, Penolong Pengarah LS41 dan dua (2) orang Penolong Pegawai Syariah. Penyelidikan mendapati daripada tahun 2009 sehingga 31 Disember 2020, pegawai yang mengendalikan runding cara tidak mempunyai sijil khusus mediasi daripada badan bertauliah. Walau bagaimanapun terdapat kursus-kursus berkaitan runding cara yang disediakan oleh pihak JKSM kepada kakitangan BSK di Sarawak. Penyelidikan mencadangkan kesemua kakitangan yang mengendalikan proses rundingcara perlu mendapatkan satu pensijilan kursus mediasi bagi memastikan pegawai yang mengendalikan mempunyai kompetensi yang sewajarnya.

\section{Cabaran Pengurusan Dana BSK JKSM di Sarawak}

Tujuan utama pengurusan dana dilaksanakan adalah untuk memberi PD kepada pemiutang penghakiman yang telah mendaftarkan kes di peringkat UKNP dan UPPP di Sarawak (Enelda, 2021). Pengurusan dana BSK JKSM di Sarawak diuruskan oleh UPD yang diuruskan oleh Penolong Akauntan Gred W29. UPD BSK juga menyalurkan bantuan wang pendahuluan nafkah kepada pemohon yang layak untuk meringankan beban sementara menunggu kes selesai sepenuhnya (Sidang Parlimen, 2019). Bantuan pendahuluan dana nafkah telah disenaraikan sebagai salah satu bantuan mekanisme bantuan kerajaan di bawah JKSM sebagaimana dinyatakan oleh SUHAKAM (2012). PD yang diberikan oleh BSK adalah bertujuan untuk membuat kutipan semula kepada Penghutang Penghakiman (Nur Zulfah \& Nur Syazwani, 2020). Jumlah kewangan yang diperuntukkan oleh BSK JKSM di Sarawak adalah sebanyak RM 300,000.00 (JKSM, 2013). Ianya untuk kegunaan pengurusan dana bagi membantu pemiutang penghakiman yang berkelayakan (Mohd Sufi, 2021). Peranan UPD adalah menyiasat dan menilai latar belakang pihak pemohon iaitu pemiutang penghakiman atau pihak yang berkepentingan sebagaimana ketetapan syarat Jawatankuasa Akaun Amanah BSK JKSS (Enelda, 2021).

Cabaran penting yang dilaksanakan UPD adalah memastikan pemiutang penghakiman yang layak sahaja diberikan pendahuluan dana selama tempoh 6 bulan dan jumlah yang diperuntukkan sama sebagaimana yang termeterai di dalam penghakiman Hakim Syarie (Mohd Sufi, 2021). Terdapat 
DOI: https://doi.org/10.47405/mjssh.v6i10.1075

permohonan yang ditolak melalui Mesyuarat Jawatankuasa Akaun Amanah BSK JKSS dan perkara ini boleh dilihat melalui jadual berikut:

Jadual 3: Statistik Keseluruhan Kes UPD BSK JKSM (Seksyen Sarawak) Tahun 2009 Sehingga Tahun $2020^{2}$

\begin{tabular}{lllllll}
\hline TAHUN & DAFTAR & $\begin{array}{l}\text { PENERIMA } \\
\text { DANA }\end{array}$ & $\begin{array}{l}\text { SELESAI } \\
\text { BAYAR }\end{array}$ & $\begin{array}{l}\text { SELESAI } \\
\text { TUTUP }\end{array}$ & $\begin{array}{l}\text { HAPUS } \\
\text { KIRA }\end{array}$ & $\begin{array}{l}\text { DALAM } \\
\text { TINDAKAN }\end{array}$ \\
\hline 2009 & 0 & 0 & 0 & 0 & 0 & 0 \\
2010 & 7 & 7 & 0 & 0 & 0 & 7 \\
2011 & 27 & 5 & 1 & 23 & 0 & 11 \\
2012 & 30 & 11 & 1 & 20 & 0 & 21 \\
2013 & 14 & 1 & 1 & 14 & 0 & 21 \\
2014 & 5 & 0 & 0 & 5 & 0 & 21 \\
2015 & 5 & 3 & 0 & 2 & 0 & 24 \\
2016 & 10 & 4 & 0 & 6 & 0 & 28 \\
2017 & 3 & 3 & 3 & 3 & 0 & 28 \\
2018 & 1 & 0 & 1 & 0 & 0 & 28 \\
2019 & 0 & 0 & 0 & 0 & 0 & 28 \\
2020 & 0 & 0 & 0 & 0 & 3 & 25 \\
JUMLAH & 102 & 34 & 7 & 73 & 3 & 25 \\
\hline
\end{tabular}

Sumber: Laporan Tahunan UPD BSK JKSS (Kemaskini sehingga 31 Disember 2020)

Berdasarkan jadual di atas menunjukkan bahawa jumlah kes yang didaftarkan di UPD BSK JKSM di Sarawak adalah sebanyak 102 kes dalam tempoh 11 tahun. Walau bagaimanapun jumlah pemiutang penghakiman yang diluluskan sebagai penerima dana hanya sebanyak 34 orang sahaja. Hal ini menunjukkan peratus kelulusan dalam 11 tahun adalah 33\% dari jumlah keseluruhan permohonan. Kesemua penerima dana sehingga 2020 adalah penerima dalam bentuk PD.

Penyelidikan mendapati bahawa pada tahun 2019 dan 2020 tiada permohonan PD dimohon di UPD ini. Hal ini adalah disebabkan pihak UPD pada tahun 2019 dan tahun 2020 memfokuskan kepada kelulusan Arahan Amanah daripada pihak Setiausaha Kewangan Negeri Sarawak bagi tujuan Bantuan Dana (Enelda, 2021). Berdasarkan fungsi dan peranan UPD ini sebagaimana diterangkan bahawa UPD BSK (Seksyen Sarawak) adalah menguruskan dua jenis saluran dana iaitu BD dan PD (BSK JKSS, 2021). Arahan Amanah Bantuan Sokongan Keluarga JKSS (AABSKJKSS) telah diluluskan oleh Setiausaha Kewangan Negeri Sarawak pada 17 Februari 2020.

Penyelidikan mendapati bahawa berdasarkan arahan amanah yang diluluskan tersebut membuka ruang kepada pemiutang penghakiman untuk mendapatkan BD berdasarkan syarat permohonan yang lebih mudah berbanding syarat bagi PD yang perlu dibuat pembayaran semula. BD juga berdasarkan perkara 7.3 AABSKJKSS dinyatakan bahawa bantuan nafkah ini boleh disalurkan secara bayaran sekaligus atau secara bertempoh dengan syarat tidak melebihi enam (6) bulan kepada mana-mana pemohon yang berkelayakan atas pertimbangan JKAAB demi menjaga kebajikan pihak yang sepatutnya. Penyelidikan mendapati berdasarkan AABSKJKSS dan juga Garis Panduan Pengurusan Dana Bantuan Sokongan Keluarga Jabatan Kehakiman Syariah Sarawak tidak terdapat satu ketetapan jumlah pembayaran bagi tujuan BD. Perkara ini dilihat menyukarkan proses penyaluran dana bagi pengurusan BD kerana jumlah yang diberikan tidak dinyatakan sebagaimana ketetapan bagi PD. Penyelidikan mencadangkan agar pihak BSK JKSM di Sarawak membuat satu jadual khusus bagi tujuan BD bagi memudahkan penyaluran jumlah yang wajar kepada pihak pemohon.

\footnotetext{
${ }^{2}$ Catatan: (1) Daftar: Pendaftaran pemohon dana BSK tahun semasa. (2) Penerima dana: Pemohonan dana yang diluluskan. (3) Selesai bayar: Penerima dana telah selesai bayar balik keseluruhan dana ke BSK. (4) Selesai Tutup: Permohonan Dana Gagal/ PMP sudah bayar habis dana
} 
Cabaran pembayaran balik daripada permohonan PD merupakan cabaran besar kepada UPD kerana terdapat pemiutang penghakiman yang tidak membayar semula PD kepada pihak UPD. Hal ini adalah kerana PD yang disalurkan kepada penerima dana/pemiutang penghakiman berasaskan kutipan balik (reimbursable) daripada penghutang penghakiman sama ada secara sekaligus atau ansuran (Mohd Amir Arifin, 2013). Penyelidikan mendapati bahawa bayaran balik PD adalah dilakukan oleh pemiutang penghakiman. Hal ini memberi kesan proses pembayaran kepada pihak UPD BSK, kecuali pihak pemiutang penghakiman dapat menerima jumlah tunggakan daripada pihak penghutang penghakiman dan dapat membayar PD sebagaimana pinjaman dibuat.

Pihak JKSM melalui inisiatif Arahan Amalan JKSM No 2. Tahun 2019 "Perintah Terhadap Penghutang Penghakiman Untuk Membayar Balik Kepada BSK Wang Pendahuluan Nafkah yang telah dibayar kepada pemiutang penghakiman dalam kes penguatkuasaan dan pelaksanaan perintah nafkah" telah membuat ketetapan bahawa "mahkamah boleh membuat perintah terhadap penghutang penghakiman untuk membayar balik kepada Bahagian Sokongan Keluarga (BSK) wang pendahuluan nafkah yang telah dibayar kepada pemiutang penghakiman dalam kes penguatkuasaan dan pelaksanaan perintah nafkah". Penyelidikan melihat bahawa hal ini merupakan satu mekanisme yang baik dan pihak BSK di Sarawak perlu lebih proaktif untuk memastikan bahawa penghutang penghakiman tetap menjelaskan tunggakan nafkah dan juga membayar PD bagi mengelakkan penganiayaan kepada pemiutang penghakiman dan juga anak-anak di bawah tanggungan.

\section{Kesimpulan}

Penguatkuasaan dan pelaksanaan penghakiman Hakim Syarie di Mahkamah Syariah berkaitan hak wanita dan hak kanak-kanak merupakan perkara yang penting yang perlu diberi perhatian demi menjaga keadilan. Pengabaian dan kecuaian pihak penghutang penghakiman dalam membayar nafkah yang ditetapkan dalam penghakiman memberi kesan penganiayaan kepada wanita dan kanak-kanak. Cabaran dalam mengendalikan penguatkuasaan penghakiman di Mahkamah Syariah melalui fungsi BSK JKSM di Sarawak telah dinyatakan sebagaimana perbincangan. Cabaran-cabaran dalam menguatkuasakan penghakiman hak wanita dan kanak-kanak wajar diberikan perhatian oleh semua pihak terutama pengurusan JKSM, JKSS dan pihak yang berkaitan. Perkara ini adalah bagi memastikan perjalanan proses penguatkuasaan penghakiman dilakukan dengan lancar melalui saluran undang-undang di Mahkamah Syariah. Penyelidikan mendapati bahawa kewujudan BSK JKSM di Sarawak merupakan satu keperluan yang signifikan bagi membantu wanita dan kanak-kanak yang teraniaya. Hak wanita dan hak kanak-kanak terutama dari aspek nafkah perlu diberi perhatian dan keutamaan bagi memastikan kebajikan wanita dan kanak-kanak terjaga. Penyelidikan menjelaskan bahawa institusi kehakiman Syariah di Malaysia tidak hanya penghakiman kes induk sahaja, tetapi juga menjalankan dan mengeluarkan penghakiman bagi kes penguatkuasaan dan pelaksanaan penghakiman.

\section{Rujukan}

Abd al-Karim Zaydan. (2011). Nizam al-Qada`fi al-Shari`ah al-Islamiyyah. Beirut: Mu'assasah alRisalah Nashirun.

Abdul Karim Mohd Nuli \& Zulzaidi bin Mahmod. (2020). Mekanisme Penguatkuasaan dan Pelaksanaan Hak Wanita Melalui Fungsi Bahagian Sokongan Keluarga Jabatan Kehakiman Syariah Sarawak, Kertas Kerja Bahagian Sokongan Keluarga, Jabatan Kehakiman Syariah Sarawak. November (2020), 1-16.

Abdul Sany Faizal Abdul Rahman lwn. Zulraini Dato`Zulkifli, Kes Mal Bil.: 14000-037-0001-2009, Mahkamah Rayuan Syariah Wilayah Persekutuan. (Kes tidak dilaporkan).

Agustin Hanafi \& Mohamad Hedhayatullah Bin Mohamad. (2018). Peran Bahagian Sokongan Keluarga Dalam Masalah Pemenuhan Nafkah Isteri Pasca Perceraian. Media Syari'ah, 20(1), 2018, 57-74. https://jurnal.ar-raniry.ac.id/index.php/medsyar/article/view/6501/3927

Akta Tatacara Mal Mahkamah Syariah (Wilayah-Wilayah Persekutuan) 1998 (Akta 585). 
Arahan Amalan JKSM No. 1 Tahun $2 \underline{0} 02$ berkenaan dengan "Kesan Keputusan Mahkamah yang Lebih Tinggi".

Arahan Amalan No. 2 Tahun 2019, "Perintah Terhadap Penghutang Penghakiman Untuk Membayar Balik Kepada BSK Wang Pendahuluan Nafkah yang telah dibayar kepada pemiutang penghakiman dalam kes penguatkuasaan dan pelaksanaan perintah nafkah".

BSK JKSS. (2021). Bahagian Sokongan Keluarga Jabatan Kehakiman Syariah Sarawak. Sarawak: JKSS.

Enelda Nurizzati Riman (Penolong Akauntan, Bahagian Sokongan Keluarga Jabatan Kehakiman Syariah Malaysia (Seksyen Sarawak)), dalam temubual pada 23 April 2021.

Fadzilah Abdul Majid. (2003). Maps and Counter-Maps: Globalised Imaginings and Local Realities of Sarawak's Plantation Agriculture. Article in Journal of Southeast Asian Studies, 34(2), June 2003, 265-284. DOI: 10.1017/S0022463403000250

Garis Panduan Pengurusan Dana Bantuan Sokongan Keluarga Jabatan Kehakiman Syariah Sarawak, diluluskan oleh YAA KHS JKSS (Pengerusi Jawatankuasa Akaun Amanah Bantuan Sokongan Keluarga Jabatan Kehakiman Syariah Sarawak.

Ibn Qudamah. (2004). al-Mughni, j.1. Lubnan: Bayt al-Afkar al-Dauliyyah.

Jabatan Kehakiman Syariah Malaysia, (2009). Mesyuarat Ahli Jawatankuasa Kerja BSK dalam Buletin JKSM (Buletin 1 Bil. 63), JKSM: Putrajaya, 12.

Jabatan Kehakiman Syariah Malaysia. (2017). Kajian Keberkesanan Bahagian Sokongan Keluarga Dalam Membantu Menyelesaikan Kes KetidakpatuhanTerhadap Perintah Nafkah Mahkamah Syariah Tahun 2011-2015. JKSM: Putrajaya.

Jabatan Kehakiman Syariah Sarawak. (2020). Pelan Antirasuah Organisasi 2021-2025. Jabatan Kehakiman Syariah Sarawak: Sarawak.

Jabatan Perangkaan Malaysia. Portal rasmi Jabatan Perangkaan Malaysia. Di akses pada 30 Julai 2021.; https://www.mycensus.gov.my/index.php/ms/produk-banci/penerbitan/banci-2010/664taburan-penduduk-dan-ciri-ciri-asas-demografi-2010

Jabatan Kehakiman Syariah Malaysia. (2013). Laporan Tahunan 2013. JKSM: Putrajaya, h. 103.

Khadijah Ibrahim (Penolong Pegawai Syariah, Bahagian Sokongan Keluarga Jabatan Kehakiman Syariah Malaysia (Seksyen Sarawak)), dalam temubual pada 23 April 2021.

Laman Web Rasmi Mahkamah Syariah Negeri Melaka, "Bahagian Sokongan Keluarga (BSK), Mahkamah Syariah Negeri Melaka" Laman Web Rasmi Mahkamah Syariah Negeri Melaka, diakses pada 5 Julai 2021. https://www.mahsyariahmelaka.gov.my/index.php/en/services/mainservices/family-support

Laporan Tahunan UPD BSK JKSS, Kemaskini sehingga 31 Disember 2020.

Laporan Tahunan UPPP BSK JKSS. Kemaskini sehingga 31 Disember 2020.

Mohamed Faouzi Mokhtar, Siti Fatimah Ahmad Maulana, Salmi Amalia Jamil \& Mohd Fariq Azaimi Apandi. (2021). Jenis-Jenis Penguatkuasaan dan Pelaksanaan Perintah di Mahkamah Syariah Wilayah Persekutuan: Satu Pengenalan dalam Nasimah Hussin et al. (eds.) dalam UndangUndang Keluaga Islam di Malaysia: Teori Amalan dan Pelaksanaan. Malaysia: JKSM \& UIAM, 307-326.

Mohd Amir Arifin@Mohd Rifin. (2013). Peguam Syarie dan Bailif: Perkongsian Pengalaman Cabaran Kutipan Balik Dana Pendahuluan Nafkah Anak. Jurnal Hukum, 37 (1) Ogos 2013, 31-62.

Mohd Amir Arifin@Mohd Rifin. (2021). Fungsi Penguatkuasaan dan Pelaksanaan Perintah Nafkah Bahagian Sokongan Keluarga Menurut Maqasid al-Shari`ah: Keberkesanannya di Bahagian Sokongan Keluarga Jabatan Kehakiman Syariah Negeri Sabah, Nasimah Hussin et al (eds.) dalam Undang-Undang Keluarga Islam di Malaysia: Teori Amalan dan Pelaksanaan. Malaysia: JKSM \& UIAM, 327-352.

Mohd Hazwan Ismail \& Jasni Sulong. (2021). Saman Penghutang Penghakiman: Keperluan Perintah Nafkah atau Perintah Tunggakan Nafkah. Journal of Contemporary Islamic Law, 6 (1), 29-38. http://www.ukm.my/jcil/wp-content/uploads/2021/06/JCIL-2021-61-Article-4.pdf

Mohd Na'im Bin Haji Mokhtar. (2015). Role of Family Support Division in The Enforcement and Execution of Syariah Court Maitenance Orders. Kertas Kerja Pembentangan IAIS pada 21 April 2015. https://iais.org.my/attach/21APR2015_ShariahCourts/IAIS_BSK_21042015.pdf.

Mohd Yusoff bin Ali lwn. Zaharah binti Ayob, Kes Mal Bil.: 070000-037-0005-2019, Mahkamah Rayuan Syariah Pulau Pinang. (kes tidak dilaporkan). 
Mohd Sufi Mohd Rani (Penolong Pengarah, Bahagian Sokongan Keluarga Jabatan Kehakiman Syariah Malaysia (Seksyen Sarawak)), dalam temubual pada 23 April 2021.

Mohd Zamri bin Abd Haziz (Penolong Pengarah Kanan, Bahagian Sokongan Keluarga Jabatan Kehakiman Syariah Malaysia (Seksyen Wilayah Persekutuan)), dalam temubual di dalam talian pada 29 Julai 2021.

Muhammad al-Zuhayli (2011), al-Mu`tamad fi al-Fiqh al-Shafi i, j. 5. Damsyiq: Dar al-Qalam.

Nur Zulfah Md Abdul Salam \& Nur Syazwani Mohd Khatib. (2020). Isu Tunggakan Nafkah: Keperluan Penubuhan Bahagian Sokongan Keluarga (BSK)". Journal of Muwafaqat, 3(1), 38-51. http://journal.kuis.edu.my/muwafaqat/images/article/vol-3/19-35_Nur-Zulfah_Isu-TunggakanNafkah-Anak-Keperluan-Biro-Sokongan-Keluarga-1.pdf.

Portal Malaysia Maps, Malaysia Travel Information, Sarawak Map Map of Sarawak in Malaysia. Di akses pada 3 Ogos 2021. http://www.malaysia-maps.com/sarawak.htm

Portal Interaktif, Jabatan Perkhidmatan Awam Malaysia. Diakses pada 3 Ogos 2021.; https://www.interactive.jpa.gov.my/ezskim/huraiankerja/HuraianKerja/L/3PL01.pdf

Prashobh Karunakaran. (2014). Electric Power Grid Optimization for The state of Sarawak as an Example Fordeveloping Countries. International journal of Electrical and Electronic

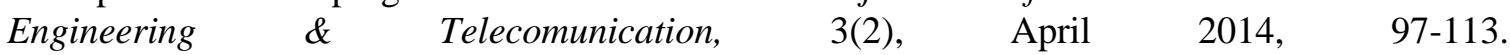
http://www.ijeetc.com/v3/v3n2/12_A0180_(97-113).pdf

Raihanah Abdullah \& Zulzaidi Mahmod. (2010). Rujuk: Peruntukan Undang-Undang dan Pelaksanaannya di Malaysia. Jurnal Syariah, 18(1), 25-52.

Roslina Che Soh@Yusoff, Nurhidayah Muhammad Hashim \& Mohd. Na'im Mokhtar. (2017). Bahagian Sokongan Keluarga Membantu Anak Selepas Perceraian: Keberkesanan, Cabaran dan Perbandingan Dengan Amalan Negara Maju. KANUN, 29(2), 60-89.

Ordinan Tatacara Mal Syariah 2001 (bab 44/2001)

Sidang Parlimen. (2017). "Jawapan Menteri Pembangunan Wanita, Keluarga dan Masyarakat", No. Soalan 75, Pemberitahuan Pertanyaan Lisan Mesyuarat Kedua, Dewan Rakyat Penggal Kelima, Parlimen Ketiga Belas. 26 julai 2017.

Sidang Parlimen. (2019). "Jawapan Menteri Pembangunan Wanita, Keluarga dan Masyarakat”, No. Soalan 20, Pemberitahuan Pertanyaan Lisan Dewan Negara, Mesyuarat Ketiga 2019, Penggal Kedua, Parlimen Keempat Belas. 09 Disember 2019. h. 2; https://www.kpwkm.gov.my/kpwkm/uploads/files/Dokumen/Jawapan\%20Dewan\%20Negara/9\% 20Dis\%202019.pdf

Sidang Parlimen. (2019). "Jawapan Menteri Pembangunan Wanita, Keluarga Dan Masyarakat", No. Soalan 20, Pemberitahuan Pertanyaan Lisan Dewan Negara, Mesyuarat Ketiga 2019, Penggal Kedua, Parlimen Keempat Belas. 09 Disember 2019.

Surat Permohonan Masuk Sebagai Peguam Syarie Pegawai Syariah LS41 bertarikh 26 Ogos 2013.

Suruhanjaya Hak Asasi Manusia Malaysia (SUHAKAM). (2012). Bantuan Ibu / Bapa Tunggal, SUHAKAM: Kuala Lumpur.

Taqi al-Din Abi Bakr bin Muhammad al-Husayni (2001), Kifayah al-Akhyar fi Halli Ghayah alIkhtisar. Beirut: Dar al-Kutub al-'Ilmiyyah.

The Official Portal of Sarawak Government, "Sarawak Population". Di akses pada 16 Jun 2021. https://sarawak.gov.my/web/home/article view/240/175/

Zaini Nasohah. (2009). Cabaran Penguatkuasaan dan Pelaksanaan Perintah Nafkah di Mahkamah Syariah Negeri Selangor dari Perspektif Peguam Syar'ie. Jurnal Undang-Undang dan Masyarakat 13 (2009), 115-128.

Zulzaidi Mahmod \& Ahmad Hidayat Buang. (2016). Kehakiman dan Penghakiman Mahkamah Syariah di Malaysia: Satu Sorotan”. Jurnal Penyelidikan Undang-undang Syariah, 1(2) (2016), 201-212. https://doi.org/10.22452/http://doi.org/10.22452/JSLR.vol1no2.3

Zulzaidi Mahmod \& Ahmad Hidayat Buang. (2021). Wakalah Peguam Syarie Terhadap Permohonan Status Pengesahan Agama Di Negeri Sarawak Berdasarkan Pendekatan Maqasid Al-Syariah, dalam Nasimah Hussin et al., (eds.) dalam Undang-Undang Keluaga Islam di Malaysia: Teori Amalan dan Pelaksanaan. Malaysia: JKSM \& UIAM. 453-383.

Zulzaidi Mahmod, Ahmad Hidayat Buang \& Afifah Baharuddin, (2021). "Penguatkuasaan dan Pelaksanaan Penghakiman Mahkamah Syariah: Kajian di Bahagian Sokongan Keluarga Jabatan Kehakiman Syariah Malaysia (Seksyen Sarawak) Terhadap Hak Wanita dan Kanak-Kanak". 
DOI: https://doi.org/10.47405/mjssh.v6i10.1075

Journal of Islamic, Social, Economics and Development (JISED), 6(39), 41-50. http://www.jised.com/PDF/JISED-2021-39-09-05.pdf

Zurul Iman Bin Zakaria, Zaini Bin Nasohah. (2019). Cabaran Pelaksanaan Penguatkuasaan UndangUndang Jenayah Syariah di Negeri Melaka. Malaysian Journal of Syariah and Law (MJSL), 7(2), Disember 2019, 13-26. 